\title{
The isotopic record of Northern Hemisphere atmospheric carbon monoxide since 1950: implications for the $\mathrm{CO}$ budget
}

\author{
Z. Wang ${ }^{1}$, J. Chappellaz ${ }^{2}$, P. Martinerie ${ }^{2}$, K. Park ${ }^{1, *}$, V. Petrenko ${ }^{3, * *}$, E. Witrant ${ }^{4}$, L. K. Emmons ${ }^{5}$, T. Blunier ${ }^{6}$, \\ C. A. M. Brenninkmeijer ${ }^{7}$, and J. E. Mak ${ }^{1}$ \\ ${ }^{1}$ Institute for Terrestrial and Planetary Atmospheres/School of Marine and Atmospheric Sciences, Stony Brook University, \\ Stony Brook, NY 11794, USA \\ ${ }^{2}$ UJF - Grenoble 1/CNRS, Laboratoire de Glaciologie et Géophysique de l'Environnement (LGGE) UMR5183, Grenoble, \\ 38041, France \\ ${ }^{3}$ Institute of Arctic and Alpine Research, University of Colorado, Boulder, CO 80309, USA \\ ${ }^{4}$ Grenoble Image Parole Signal Automatique (GIPSA-lab), Université Joseph Fourier/CNRS, BP 46, 38 402 Saint Martin \\ d'Hères, France \\ ${ }^{5}$ National Center for Atmospheric Research, Atmospheric Chemistry Division, Boulder CO 80301, USA \\ ${ }^{6}$ Centre for Ice and Climate, Niels Bohr Institute, University of Copenhagen, Juliane Maries vej 30, \\ 2100 Copenhagen $\varnothing$, Denmark \\ ${ }^{7}$ Max Planck Institute for Chemistry, 55128 Mainz, Germany \\ * now at: Division of Polar Climate Research, Korea Polar Research Institute, Incheon, South Korea \\ ** now at: Department of Earth and Environmental Sciences, University of Rochester, Rochester, NY, USA
}

Correspondence to: Z. Wang (zhihui.wang@stonybrook.edu)

Received: 24 October 2011 - Published in Atmos. Chem. Phys. Discuss.: 15 November 2011

Revised: 4 April 2012 - Accepted: 24 April 2012 - Published: 16 May 2012

\begin{abstract}
We present a 60-year record of the stable isotopes of atmospheric carbon monoxide (CO) from firn air samples collected under the framework of the North Greenland Eemian Ice Drilling (NEEM) project. CO concentration, $\delta^{13} \mathrm{C}$, and $\delta^{18} \mathrm{O}$ of $\mathrm{CO}$ were measured by gas chromatography/isotope ratio mass spectrometry (gc-IRMS) from trapped gases in the firn. We applied LGGE-GIPSA firn air models (Witrant et al., 2011) to correlate gas age with firn air depth and then reconstructed the trend of atmospheric $\mathrm{CO}$ and its stable isotopic composition at high northern latitudes since 1950. The most probable firn air model scenarios show that $\delta^{13} \mathrm{C}$ decreased slightly from $-25.8 \%$ in 1950 to $-26.4 \%$ in 2000 , then decreased more significantly to $-27.2 \%$ in $2008 . \delta^{18} \mathrm{O}$ decreased more regularly from $9.8 \%$ in 1950 to $7.1 \%$ in 2008 . Those same scenarios show CO concentration increased gradually from 1950 and peaked in the late 1970s, followed by a gradual decrease to present day values (Petrenko et al., 2012). Results from an isotope mass balance model indicate that a slight increase, followed by a large reduction, in $\mathrm{CO}$ derived from fossil fuel combus-
\end{abstract}

tion has occurred since 1950. The reduction of CO emission from fossil fuel combustion after the mid-1970s is the most plausible mechanism for the drop of $\mathrm{CO}$ concentration during this time. Fossil fuel $\mathrm{CO}$ emissions decreased as a result of the implementation of catalytic converters and the relative growth of diesel engines, in spite of the global vehicle fleet size having grown several fold over the same time period.

\section{Introduction}

The importance and interest for measuring atmospheric $\mathrm{CO}$ arises from its significant role in the chemistry of the troposphere, since $\mathrm{CO}$ is a major sink for hydroxyl radical $(\mathrm{OH})$. Hydroxyl radical is the most important oxidant in Earth's atmosphere, thus its abundance affects the lifetimes of reactive greenhouse gases and ozone depleting gases. In addition to its significance for $\mathrm{OH}$, oxidation of $\mathrm{CO}$ by $\mathrm{OH}$ acts as a source (in high $\mathrm{NO}_{\mathrm{x}}$ conditions) or a sink (in low $\mathrm{NO}_{\mathrm{x}}$ conditions) for ozone, which is a major contributor to ground 
level photochemical smog (Levy, 1971; Logan et al., 1981). The major sources of atmospheric $\mathrm{CO}$ in today's atmosphere include oxidation of methane $\left(\mathrm{CH}_{4}\right)$ and non-methane hydrocarbons (NMHC), biomass burning, fossil fuel and biofuel combustion (Duncan et al., 2007; Seiler, 1974). In addition to a complex mixture of sources, atmospheric $\mathrm{CO}$ has a relatively short atmospheric lifetime (weeks to months), resulting in large temporal and spatial variations and complicating the global $\mathrm{CO}$ budget. Certain sources produce atmospheric $\mathrm{CO}$ with distinct ratios of ${ }^{13} \mathrm{C} /{ }^{12} \mathrm{C}$ and ${ }^{18} \mathrm{O} /{ }^{16} \mathrm{O}$ (Stevens et al., 1972; Stevens and Wagner, 1989; Brenninkmeijer, 1993), hence isotopic information can help to determine the various sources and their relative magnitudes (Mak et al., 2003; Mak and Kra, 1999; Mak and Brenninkmeijer, 1998; Röckmann et al., 2002; Manning et al., 1997). Bergamaschi et al. (2000a, b) reported that including isotope data in model simulations helps to constrain the source strengths of $\mathrm{CO}$. Thus, measuring the stable isotopes of $\mathrm{CO}$ from firn and ice cores would help constrain relative source strengths in the past. To date, however, few such observations exist. Polar ice core analyses have provided hints about the evolution of $\mathrm{CO}$ from its concentration (Ferretti et al., 2005; Haan et al., 1996; Haan and Raynaud, 1998) and isotopic ratios over the last few centuries. For example, recent work revealed the importance of biomass burning changes in the Southern Hemisphere during the past 650 years (Wang et al., 2010). Also, a recent study based on firn air analyses provided a reconstruction of atmospheric CO from Berkner Island, Antarctica, roughly covering the last four decades, which is important for understanding the past $\mathrm{CO}$ budget in the Southern Hemisphere (Assonov et al., 2007). The only available firn air CO measurements from the Northern Hemisphere are from samples collected from the summit of Devon Island Ice Cap, Nunavut, Canada $\left(75^{\circ} 20^{\prime} \mathrm{N} ; 82^{\circ} 08^{\prime} \mathrm{W}\right.$; $1929 \mathrm{~m}$ a.s.l.) in April 1998 (Clark et al., 2007). However, they showed the existence of in-situ CO production at depth, which is likely related to the relatively high temperature of this site, resulting in systematic summer melting and thick melt layers in the firn column, as well as relatively high levels of impurities in Devon Island ice (Clark et al., 2007).

Greenland ice core records have shown that $\mathrm{CO}$ concentrations at high northern latitudes increased from $\sim 90 \mathrm{ppbv}$ to $\sim 110$ ppbv between 1800 and 1950 (Haan et al., 1996), which is believed to result from rising anthropogenic emissions, such as fossil fuel combustion (Marland et al., 2008), and from growing methane concentration. Today's annual mean $\mathrm{CO}$ concentration over Summit, Greenland $\left(72.58^{\circ} \mathrm{N}\right.$; $38.48^{\circ} \mathrm{W} ; 3238 \mathrm{~m}$ a.s.l.) is around $120 \mathrm{ppbv}$ based on flask measurements by National Oceanic and Atmospheric Administration Global Monitoring Division (NOAA/GMD) (Novelli and Masarie, 2010). Therefore, comparing ice core and direct atmospheric $\mathrm{CO}$ measurements suggests that significant variations of $\mathrm{CO}$ concentration and concurrent $\mathrm{CO}$ budget have occurred at high northern latitudes over the last 60 years. However, there is very limited information about the CO record in the Northern Hemisphere prior to 1980. The only available atmospheric CO concentration for 1950-1951 was deduced indirectly from infrared total column amount measurements at the Jungfrau Scientific Station in the Swiss Alps (Rinsland and Levine, 1985). Sporadic field measurements of atmospheric CO started in the early 1970s (Seiler and Junge, 1970; Seiler, 1974; Heidt et al., 1980) and systematic global monitoring of atmospheric $\mathrm{CO}$ by National Oceanic and Atmospheric Administration Global Monitoring \& Diagnostics Laboratory (NOAA/CMDL) started in the late 1980s (Novelli et al., 1992, 1994). An increasing trend of atmospheric $\mathrm{CO}$ at Cape Meares, Oregon $\left(45^{\circ} \mathrm{N} ; 125^{\circ} \mathrm{W}\right)$, was first recognized in 1979-1982 (Khalil and Rasmussen, 1984), and a decrease in global CO concentrations was observed in the early 1990s (Khalil and Rasmussen, 1994; Novelli et al., 1994).

In this study, measurements of $\mathrm{CO}$ concentration and stable isotopic ratios are carried out on Greenland firn air samples to provide the longest $\mathrm{CO}$ isotope records for the Northern Hemisphere. Because of signal smoothing by diffusion of gases in firn air (Schwander and Stauffer, 1984), firn air measurements do not provide discretely resolved time evolutions of trace gas concentrations and isotopic ratios. Models of trace gas transport in firn are thus used to derive a reconstruction from the observed firn air profile. The evolving $\mathrm{CO}$ budget over the last 50 years at high northern latitudes is then calculated based on measurements of $\mathrm{CO}$ concentration, $\delta^{13} \mathrm{C}, \delta^{18} \mathrm{O}$ and an isotope mass balance model (Wang et al., 2010; Mak and Kra, 1999).

\section{Experimental procedures}

Eighteen firn air samples from surface to $75.9 \mathrm{~m}$ of depth were obtained close to the NEEM deep drilling site (77.445 ${ }^{\circ} \mathrm{N} ; 51.066^{\circ} \mathrm{W} ; 2484 \mathrm{~m}$ a.s.1.) in July 2008. Details of the NEEM 2008 firn air campaign have been described recently (Buizert et al., 2011). The NEEM firn air samples used here were collected from the 2008 EU borehole (Buizert et al., 2011) in 31 SilcoCan canisters (Restek Inc.) at a pressure of 2.8 bar. Before being filled, the SilcoCans already included polar firn air from previous expeditions, at pressure above ambient. The firn air was dried through a $\mathrm{Mg}\left(\mathrm{ClO}_{4}\right)_{2}$ trap placed inline between the pumping unit and the SilcoCan. The filling procedure included evacuation of the SilcoCan first, then filling to $1 \mathrm{~atm}$ above ambient by evacuation twice, and lastly filling to 2.8 bar. The surface sample was collected on 16 July 2008 at 10:00 p.m. local time. The air samples were analyzed using a previously established protocol (Wang and Mak, 2010) at Stony Brook University in November/December 2008. Concentration and isotopic ratios $\left(\delta^{13} \mathrm{C}\right.$ and $\left.\delta^{18} \mathrm{O}\right)$ were determined by cryogenic vacuum extraction, gas chromatographic separation, and continuous-flow isotope ratio mass spectrometry (CFIRMS) (Wang and Mak, 2010). A $100 \mathrm{ml}$ sample (STP) was 
processed at a flow rate of $50 \mathrm{ml} \mathrm{min}^{-1}$ for each run and 3 to 12 replicates were conducted for each sample. Calibration gas $\left(\mathrm{CO}\right.$ mixing ratio $141 \mathrm{ppbv} ; \delta^{13} \mathrm{C}=-45.56 \%$ VPDB; $\delta^{18} \mathrm{O}=-1.94 \%$ VSMOW) (Wang and Mak, 2010) was processed frequently between firn air samples. Analytical precision of 3 ppbv $( \pm 1 \sigma)$ for $\mathrm{CO}$ concentration, $0.3 \%$ o $( \pm 1 \sigma)$ for $\delta^{13} \mathrm{C}$ and $0.8 \% \quad( \pm 1 \sigma)$ for $\delta^{18} \mathrm{O}$ was obtained for the $100 \mathrm{ml}$ firn air samples (STP).

Firn air samples were also collected from the same borehole (EU borehole in glass flasks and analyzed for CO concentration at CSIRO, Australia; University of Heidelberg, Germany; as well as at NOAA/GMD, USA, allowing for inter-laboratory comparison. In addition, the 2008 US borehole (Buizert et al., 2011) was sampled and measured for CO concentration at NOAA/CMDL and the University of Heidelberg (Petrenko et al., 2012).

\section{Results}

$\mathrm{CO}$ concentration and isotope profiles from NEEM firn air are shown in Fig. 1. A comprehensive discussion of CO concentration will be presented in a separate paper (Petrenko et al., 2012); in this work, the CO concentration is mainly used to intercompare our $\mathrm{CO}$ observations with other data sets. Good agreement of the $\mathrm{CO}$ concentration trend was observed among four independent labs, although there are differences in absolute values, most probably reflecting different calibration scales (Petrenko et al., 2012). The concentration profiles show that, on the Stony Brook scale, [CO] increases from $85 \mathrm{ppbv}$ to $140 \mathrm{ppbv}$ between the surface and $20 \mathrm{~m}$ of depth, followed by a relatively constant value of around $130 \mathrm{ppbv}$ to a depth of $60 \mathrm{~m}$. The first feature results from the seasonal variation of atmospheric $\mathrm{CO}$ concentrations, which ranged from $\sim 160$ ppbv in February 2008 to $\sim 90 \mathrm{ppbv}$ in August 2008 in Summit, Greenland $\left(72.58^{\circ} \mathrm{N}\right.$; $38.48^{\circ} \mathrm{W} ; 3238 \mathrm{~m}$ a.s.1.) (Novelli and Masarie, 2010). The surface observation on 16 July 2008 thus lies on the downward trend of the seasonal cycle, whereas below about $35 \mathrm{~m}$ depth, the observed firn air CO concentration already reflects an average atmospheric concentration spanning at least one year. A gradual increase of $\mathrm{CO}$ concentration is then observed from $60 \mathrm{~m}$ to $70 \mathrm{~m}$, with a measured peak value of around $155 \mathrm{ppbv}$ at $70 \mathrm{~m}$, followed by a gradual decrease to the bottom of the firn.

The CO concentration peak at $70 \mathrm{~m}$ in the NEEM firn layer is reproduced in deep NGRIP (North Greenland Ice Core Project) firn, as well as deep firn at Summit, Greenland, with similar peak values (Petrenko et al., 2012), indicating CO is well preserved in NEEM firn. The measured mixing ratio profiles for other trace gases such as $\mathrm{SF}_{6}$ also confirm that most NEEM samples are free of contamination from ambient air and that contamination in the deepest/oldest samples is minimal (Buizert et al., 2011).

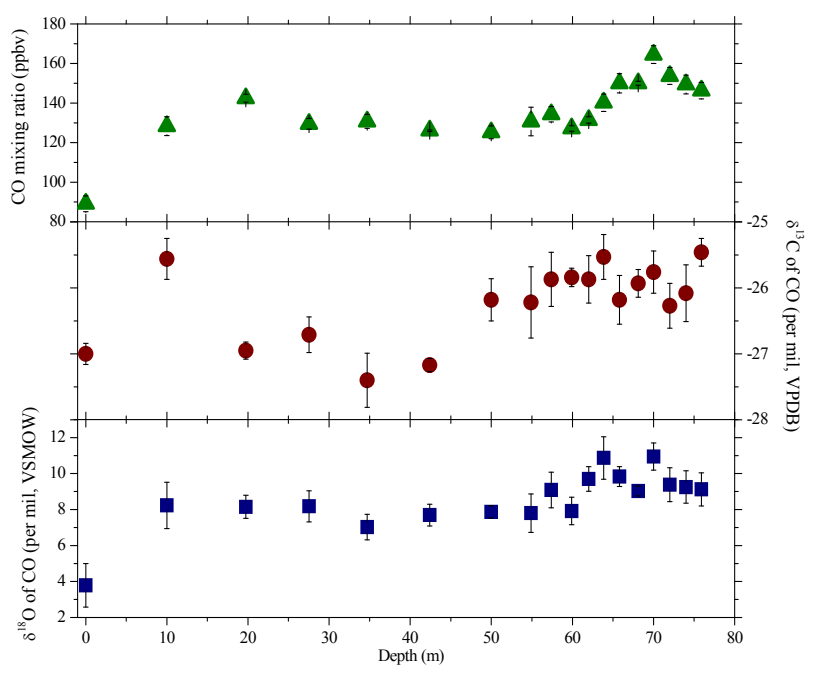

Fig. 1. Observations for the mixing ratio and isotopic ratios of $\mathrm{CO}$ in NEEM firn air collected from the EU 2008 borehole. Top panel: [CO] in this study (triangles); middle panel: $\delta^{13} \mathrm{C}$ of $\mathrm{CO}$ in this study (circles); bottom: $\delta^{18} \mathrm{O}$ of $\mathrm{CO}$ in this study (squares). Error bars are $\pm 1 \sigma$ standard deviation on replicates of 3 to 12 measurements at each depth level.

A seasonal imprint of both $\delta^{13} \mathrm{C}$ and $\delta^{18} \mathrm{O}$ in the first 0 $50 \mathrm{~m}$ is observed in NEEM firn (Fig. 1 and Sect. 4.2). $\delta^{13} \mathrm{C}$ of atmospheric CO at Alert was -29\%o in September 1997 and $-24 \%$ in May 1998, where $\delta^{18} \mathrm{O}$ ranged from $-2 \%$ in August 1997 to $10 \%$ in February 1998 (Röckmann et al., 2002). The isotope data reflect more enriched values for $\delta^{13} \mathrm{C}$ below $50 \mathrm{~m}$ and for $\delta^{18} \mathrm{O}$ below $60 \mathrm{~m}$. Isotopic fractionation is expected due to gravitational separation, but its magnitude can be estimated. As the mass difference between ${ }^{13} \mathrm{CO}$ and ${ }^{12} \mathrm{CO}$ is $1 \mathrm{amu}$, the enrichment with depth of ${ }^{13} \mathrm{CO}$ with respect to the ${ }^{12} \mathrm{CO}$ resulting from gravitational fractionation must be similar as gravitational enrichment of ${ }^{15} \mathrm{~N}-{ }^{14} \mathrm{~N}$ versus ${ }^{14} \mathrm{~N}-{ }^{14} \mathrm{~N}$ of molecular nitrogen (same mass difference). In NEEM firn, $\delta^{15} \mathrm{~N}$ of $\mathrm{N}_{2}$ amounts to $0.3 \%$ in the deepest air samples (Buizert et al., 2011). Thus, gravitational enrichment is estimated to be $0.3 \%$ or for $\delta^{13} \mathrm{C}$ and $0.6 \%$ or for $\delta^{18} \mathrm{O}$ over the depth of the firn, and cannot account for all of the observed enrichment of the heavier $\mathrm{CO}$ isotopologues. The remaining isotopic variation is a result of diffusion gradients in the NEEM firn as well as changes in the isotopic abundance of $\mathrm{CO}$ over time.

\section{LGGE-GIPSA models of gas transport in firn}

\subsection{Model description}

A 1-D inverse model, initially developed by Rommelaere et al., 1997, and recently extended to isotopologues, was used to reconstruct the atmospheric trends of CO isotopes. The full procedure involves a suite of three models of gas transport 
in firn (Witrant et al., 2011). The LGGE-GIPSA forward and diffusivity optimization models used in this study (Witrant et al., 2011) showed very good performances in a model comparison study based on the two NEEM 2008 firn air pumping operations (Buizert et al., 2011).

Once the forward model has been properly constrained for a given firn air pumping site, the second step is to calculate the atmospheric trend scenario. An infinite number of solutions can fit the data satisfactorily within uncertainties, thus a regularization term aiming at selecting the simplest solution is used (Rommelaere et al., 1997). It is based on bounding the values of the scenario's second derivative. Isotopic records in firn are expressed as the deviation from a reference of a concentration ratio between the major isotopologue and the target minor isotopologue ( $\delta$ unit). The variations with depth of isotopic ratios in firn can be due to atmospheric variations in the major isotopologue concentrations, the minor isotopologue concentrations, or isotopic fractionation in firn (see e.g. Trudinger et al., 1997). The scenario reconstruction method used here is based on separating the effects of the major and minor isotopologues on their concentration ratio. The effect of the major isotopologue is first evaluated by using its atmospheric time trend as input to the forward model. A second forward model simulation calculates minor isotopologue concentrations in firn resulting from the latter scenario and a constant isotopic ratio in the atmosphere. Then the isotopic ratios measured in firn are corrected from this major isotopologue effect. This correction approach has been used in previous studies (Trudinger et al., 1997; Francey et al., 1999). The corrected values are inverted, assuming a constant atmospheric concentration of the major isotopologue. The final evaluation of the reconstructed atmospheric isotopic ratio is done by running again both the major and minor isotopologue trends in the forward model (the concentration of the minor isotope is calculated with the concentration of the major isotope and regular conversion from $\delta$ value to minor isotope concentration) in order to check the consistency of the resulting isotopic ratios in firn with the measured values.

In the case of $\mathrm{CO}$ isotopes, a data-based $\mathrm{CO}$ concentration trend at Barrow, Alaska $\left(71.32^{\circ} \mathrm{N} ; 156.61^{\circ} \mathrm{W} ; 11 \mathrm{~m}\right.$ a.s.l. $)$ is available only since 1988 (Novelli and Masarie, 2010), thus an inverse model CO concentration trend (Petrenko et al., 2012) is used in the reconstruction of atmospheric isotopic ratios for $\mathrm{CO}$ isotopes. Sensitivity tests were performed in order to evaluate the effect of the uncertainty of the past $\mathrm{CO}$ trend on isotope reconstructions (see Sect. 4.4).

\subsection{Impact of seasonal cycles on $\mathrm{CO}$ firn signals}

Atmospheric $\mathrm{CO}$ and its stable isotopic ratios undergo strong seasonal variations (Mak et al., 2003; Manning et al., 1997; Röckmann et al., 2002). In this section, we aim at understanding how and up to which depth firn results are affected by seasonality. The regularization term used in the inverse model for long-term atmospheric trend reconstruction re- quires the use of a small second derivative of the scenario. Thus, the inverse model scenarios cannot capture seasonal changes. This mathematical limit can be grasped physically from the fact that a $\sim 50$-year long scenario is reconstructed from 18 measurement depths in the firn. Our sampling resolution does not allow for a trend reconstruction at sub-annual time scale. As a consequence, the reconstruction of a long term atmospheric trend requires us to discard the firn data strongly influenced by seasonality and/or correct the data from the effect of seasonality. However, the effect of seasonality on concentrations in firn can be assessed using atmospheric data-based scenarios as input to the forward firn model.

Mean atmospheric seasonal cycles were estimated from atmospheric records of $\mathrm{CO}, \delta^{13} \mathrm{C}$, and $\delta^{18} \mathrm{O}$ of $\mathrm{CO}$ in Iceland (Supplement). The effect of seasonality on firn records is estimated in Fig. 2 by comparing the impact of two scenarios with and without seasonality. As recent trends in $\mathrm{CO}$ isotopes are not well known, we assume constant mean annual values ([CO] $=132 \mathrm{ppbv}, \delta^{13} \mathrm{C}=-27.5 \%$, and $\delta^{18} \mathrm{O}=8 \%$ o) for the recent past. The difference between scenarios with/without seasonality indicates that $\mathrm{CO}$ isotopic ratios in firn can be seasonally influenced down to $50 \mathrm{~m}$ depth, and that most of the observed $\delta^{13} \mathrm{C}$ and $\delta^{18} \mathrm{O}$ variations in the upper $\sim 40 \mathrm{~m}$ of the NEEM firn can be explained by the effect of seasonality (Fig. 2). However, the amplitude of the seasonal effect is small between 30 and $40 \mathrm{~m}$ depth (less than $0.1 \%$ ). Between 20 and $30 \mathrm{~m}$, sub-monthly time scale events in the atmosphere still potentially have a significant influence.

For the purpose of inverse modeling, our estimate of the seasonal effect was considered as acceptable when the corrected values fall within the mean uncertainty of the measured values. Thus, the uppermost 3 data points for $\delta^{13} \mathrm{C}$ and 2 data points for $\delta^{18} \mathrm{O}$ of $\mathrm{CO}$ were discarded. Seasonally corrected data were used for deeper firn samples.

\subsection{Atmospheric trend reconstructions for $\delta^{13} \mathrm{C}$ and $\delta^{18} \mathrm{O}$ of $\mathrm{CO}$}

Best estimate atmospheric trends of $\mathrm{CO}$ concentration (from Petrenko et al., 2012), $\delta^{13} \mathrm{C}$, and $\delta^{18} \mathrm{O}$ of $\mathrm{CO}$ are shown in Fig. 3. $\mathrm{CO}$ concentration trend will be discussed in Petrenko et al., 2012. We focus on CO isotopes here. Atmospheric trends of $\delta^{13} \mathrm{C}$ and $\delta^{18} \mathrm{O}$ are required to explain the observed variations in deep firn but show small amplitude variations. The bell shape of the firn signals around $65 \mathrm{~m}$ depth (Fig. 1) is mainly explained by the effect of the major isotopologue which peaks at similar depth in the firn. The root mean square deviation of the model results with respect to firn data (RMSD $\mathrm{Rod}_{\text {mo }}$ ) is $0.27 \%$ for $\delta^{13} \mathrm{C}$ and $0.65 \%$ for $\delta^{18} \mathrm{O}$. These numbers are comparable to the experimental uncertainties. Varying the weight of the regularization term (e.g. the imposed smoothness of the scenario) has more influence on $\delta^{13} \mathrm{C}$ than $\delta^{18} \mathrm{O}$ (Fig. 4). The optimal solution for $\delta^{18} \mathrm{O}$ is nearly a linear trend with time. With a less regular 

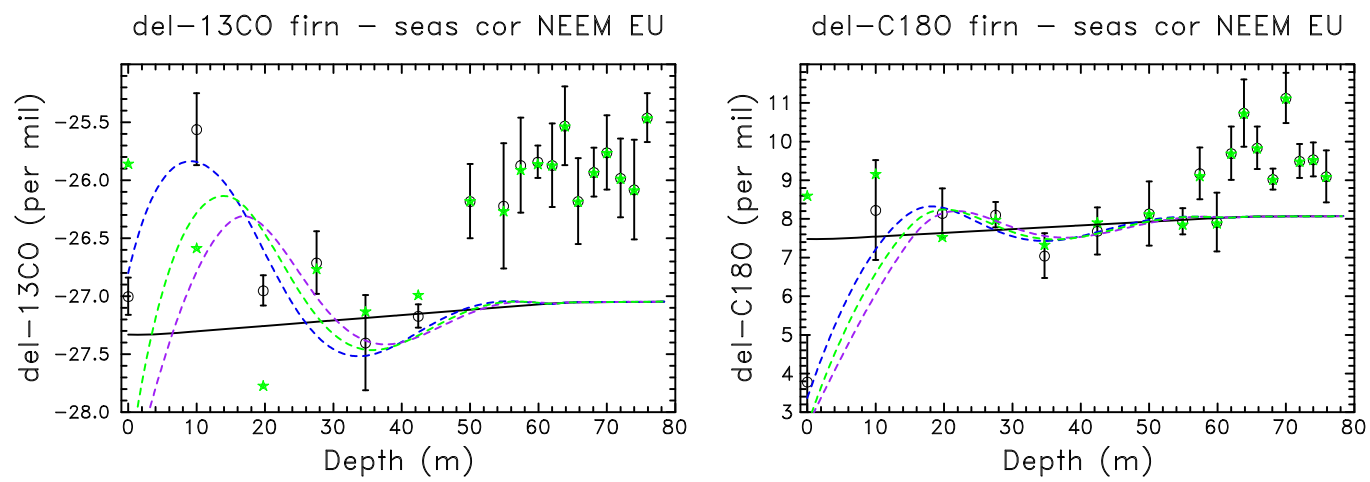

Fig. 2. Effect of atmospheric seasonality on $\delta^{13} \mathrm{C}$ (left) and $\delta^{18} \mathrm{O}$ (right) of CO in NEEM firn. Measured isotopic ratios are shown as black circles with error bars, and green stars show $\delta^{13} \mathrm{C}$ and $\delta^{18} \mathrm{O}$ values corrected from the effect of seasonality. Simulated values with deseasonalized atmospheric scenarios are plotted as black lines; simulated values with atmospheric seasonal cycles are plotted as green dashed lines. The differences between uncorrected (black circles) and corrected (green stars) firn data are the same as the differences between simulated values without (black lines) and with (green lines) seasonality. The increasing isotopic ratios with depth obtained from constant scenarios (black lines) illustrate the effect of gravitational fractionation. The purple and blue dashed lines show the effect of shifting the final date of the simulation (firn drilling date) by plus or minus 15 days, respectively. They are intended to illustrate the effect of atmospheric variations at a sub-monthly time scale.

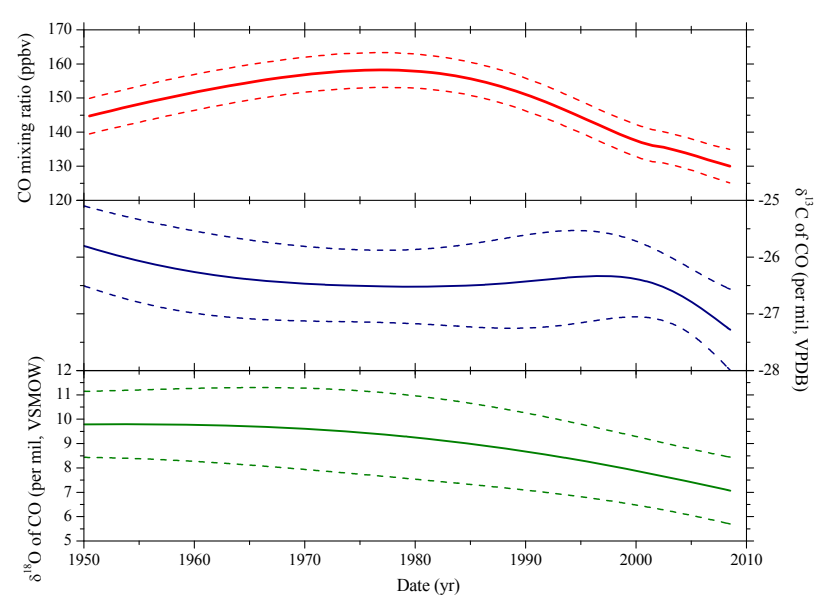

Fig. 3. Best estimate trends of CO concentration (Petrenko et al., 2012) and isotopic ratios simulated by LGGE-GIPSA models of gas transport in firn. Best estimate time trends and uncertainty envelopes in firn are shown as continuous lines and dashed lines, respectively.

scenario, the model essentially tries to reduce the data-model discrepancy with the data point at $70 \mathrm{~m}$ depth. However, due to the gas age overlaps with the neighboring data points at 68 and $72 \mathrm{~m}$ depth, an exact fit of the $70 \mathrm{~m}$ depth data would require a very strong and unrealistic variation in the atmospheric scenario. The variations of $\mathrm{RMSD}_{\text {mod }}$ when varying the weight of the regularization term by five orders of magnitudes are small: $0.63-0.70 \%$. RMSD mod $_{\text {varies more }}$ strongly for $\delta^{13} \mathrm{C}$ of CO: $0.19-0.31 \%$, in relation with a less stable behavior of the solution (Fig. 4). In the firn, a less regular scenario for $\delta^{13} \mathrm{C}$ produces a steeper slope in the upper firn $(0-60 \mathrm{~m})$. The higher/lower atmospheric values with respect to the optimal scenario can be related to higher/lower values in different depth ranges in firn which result in the oscillating behavior of the scenario (the increasing values below $65 \mathrm{~m}$ are associated with an atmospheric increase before 1952). The decreasing atmospheric trend in $\delta^{13} \mathrm{C}$ in 2004 2008 is overall consistent with atmospheric data in Iceland (Wang et al., 2012) but it should be noted that at such a short time scale, the model may not discriminate between the multi-annual trend and sub-annual events such as seasons with strong biomass burning events.

\subsection{Effect of past $\mathrm{CO}$ trend on isotope reconstructions}

Isotopic ratios in firn are sensitive to variations of both the major and minor isotope (see Sect. 4.1). Here we test the effect of uncertainties in the past $\mathrm{CO}$ trend on isotopic ratios. Eleven $\mathrm{CO}$ scenarios were built, aiming at covering the range of uncertainties (see Supplement Fig. S2). Five of them use NEEM EU hole only CO data and smoothing factors differing by five orders of magnitude, the others use different ways of averaging single or multi-site simulations and connecting them to the ice core data (Haan et al., 1996) (with or without rescaling). Supplement Fig. S2 shows the impact on $\delta^{13} \mathrm{C}$ and $\delta^{18} \mathrm{O}$ of using these different $\mathrm{CO}$ scenarios to reconstruct atmospheric isotopic trends. The induced differences in both the atmospheric trends and the matching of firn data fall well within uncertainties illustrated in Figs. 3 and 4. This indicates that the impact on $\delta^{13} \mathrm{C}$ and $\delta^{18} \mathrm{O}$ of using these different $\mathrm{CO}$ scenarios to reconstruct atmospheric isotopic trends is very small. 

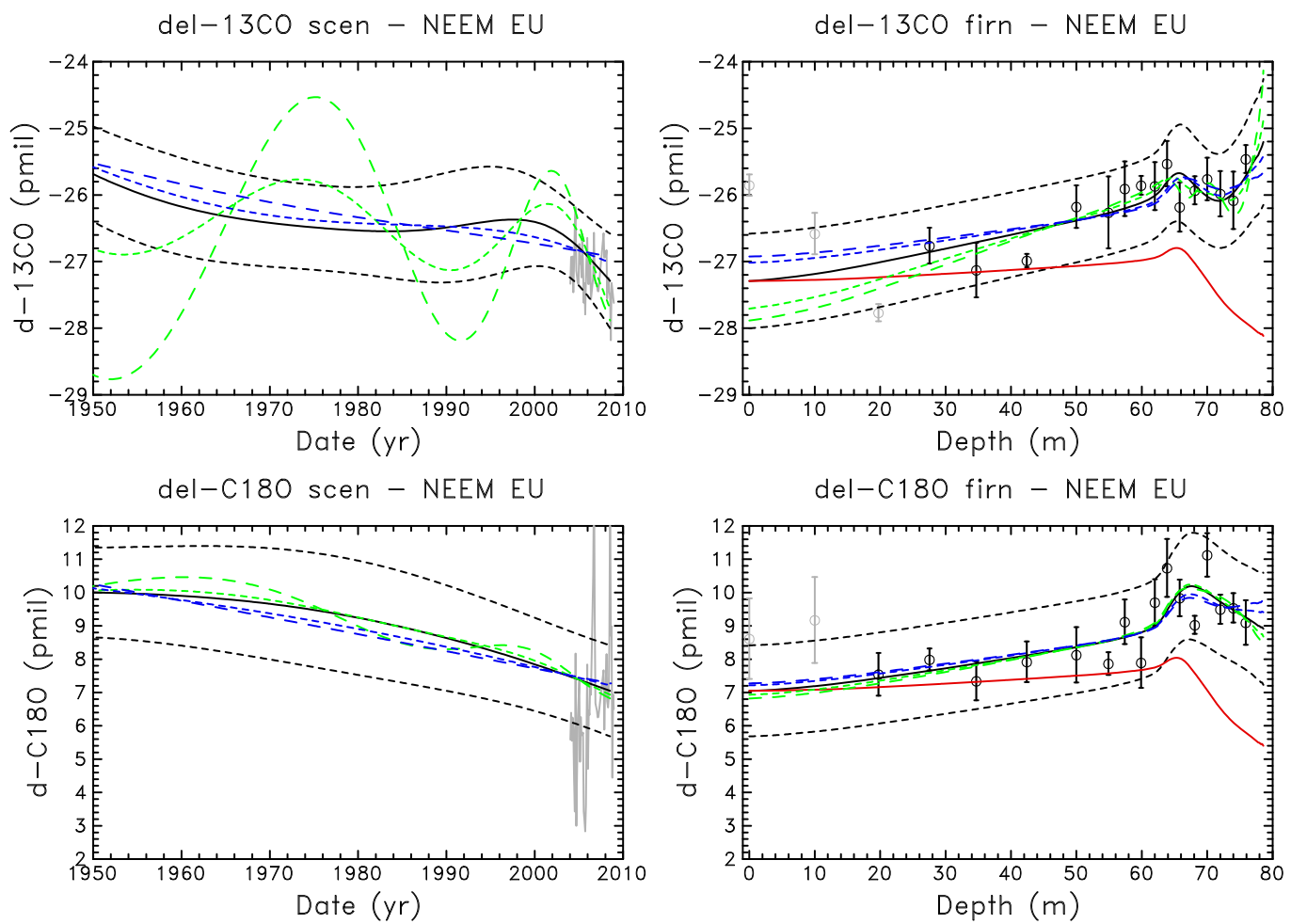

Fig. 4. Best estimate trends of $\mathrm{CO}$ isotopes and influence of the regularization factor. Best estimate time trends (in black) and the resulting isotopic ratios in firn are the same as in Fig. 4. The red lines on the right panels show the effect of the CO trend scenario with constant atmospheric isotopic ratio. Blue lines show the effect of increasing the weight of the regularization term by a factor of 10 (short dashed lines) and 100 (long dashed lines). Green lines show the effect of decreasing the weight of the regularization term by a factor of 10 (short dashed lines) and 100 (long dashed lines). The circles with error bars on the right panels show the measurements, and those in grey were not used in the scenario reconstruction. Grey lines on the left panels show the de-seasonalized atmospheric trends in Iceland (Wang et al., 2012).

\subsection{Sensitivity to the deepest measurement for $\delta^{13} \mathrm{C}$ of $\mathrm{CO}$}

Trace gas concentrations in deep firn are affected by air removal from the firn by trapping in bubbles. They also undergo wide age distributions. For example, the modeled concentration in firn at the deepest measurement level is dependent on scenario values at earlier dates of its mean age. Thus, the early scenario values are only partially constrained by firn data.

Supplement Fig. S3 illustrates the effect of not using the deepest measurement of $\delta^{13} \mathrm{C}$ as a constraint for the inverse model. The results remain within error bars between 1940 and 2008 but lead to a somewhat different shape of the scenario for the whole period. Figure S3 suggests that the early trend in $\delta^{13} \mathrm{C}$ (before $\sim 1975$ ) is influenced by the last data point.

\section{Isotope mass balance model and discussions}

The variation of CO concentration and the shifts of both isotopic ratios since 1950 indicate significant variations in CO source strengths and/or CO loss rates. Isotopic ratios help to distinguish between $\mathrm{CO}$ from different sources (Brenninkmeijer, 1993; Stevens et al., 1972; Stevens and Wagner, 1989). Notably, $\mathrm{C}^{18} \mathrm{O}$ is a good tracer for distinguishing combustion-derived $\mathrm{CO}$ (e.g. fossil fuel combustion or biomass burning) from non-combustion-derived $\mathrm{CO}$ (e.g. hydrocarbon oxidation) (Brenninkmeijer and Röckmann, 1997). ${ }^{18} \mathrm{O}$ enriched sources are fossil fuel combustion, biomass burning, and biofuel burning (Stevens et al., 1972; Stevens and Wagner, 1989; Kato et al., 1999; Brenninkmeijer and Röckmann, 1997).

An isotope mass balance model is used to quantify the different source partitioning (Mak and Kra, 1999; Wang et al., 2010). The isotope mass balance model used in this study includes the following equations:

$\sum_{i=1}^{7}\left[\mathrm{CO}_{i}\right]=[\mathrm{CO}]$

$\sum_{i=1}^{7}\left[\mathrm{CO}_{i}\right] \times \delta^{18} \mathrm{O}_{i}=[\mathrm{CO}] \times \delta^{18} \mathrm{O}$ 
where $i$ denotes a given $\mathrm{CO}$ source: fossil fuel combustion, methane oxidation, NMHC oxidation, biofuel burning, biomass burning, direct biogenic and oceanic emission. $\left[\mathrm{CO}_{i}\right]$ stands for $\mathrm{CO}$ concentration from each source and $[\mathrm{CO}]$ is the atmospheric $\mathrm{CO}$ concentration derived from Greenland firn air measurements and diffusion model simulations (Petrenko et al., 2012). $\delta^{18} \mathrm{O}_{i}$ is the $\delta^{18} \mathrm{O}$ source signature at high northern latitude and $\delta^{18} \mathrm{O}$ is the $\delta^{18} \mathrm{O}$ of atmospheric CO from NEEM firn air measurements and LGGEGIPSA model simulations in this study (Fig. 3). Both the best estimate of $\mathrm{CO}$ concentration and $\delta^{18} \mathrm{O}$ values and envelope values from LGGE-GIPSA model simulations will be used to calculate the mean source partitioning and uncertainties.

Only $\delta^{18} \mathrm{O}$ data are used in the mass balance model. $\delta^{13} \mathrm{C}$ data are not used because $\delta^{13} \mathrm{C}$ signatures for different Northern Hemisphere $\mathrm{CO}$ sources are not as isotopically distinct. For example, the range of values of $\delta^{13} \mathrm{C}$ from biomass burning largely overlaps with the range of values from NMHCderived CO. A more detailed discussion of $\delta^{13} \mathrm{C}$ data is provided in the Supplement .

$\delta^{18} \mathrm{O}$ signatures for different sources and [CO] contributions from these sources in the modern atmosphere at high northern latitude (Iceland: 63 $15^{\prime} \mathrm{N} ; 20^{\circ} 09^{\prime} \mathrm{W}$ ) have been determined using MOZART-4 model simulations (Model for Ozone and Related Chemical Tracers, version 4) (Emmons et al., 2010; Park, 2010) (Table 1). Simulations at other high northern latitudes such as Alert $\left(78.5^{\circ} \mathrm{N} ; 11.5^{\circ} \mathrm{W}\right)$ and Spitsbergen $\left(81.3^{\circ} \mathrm{N} ; 62.3^{\circ} \mathrm{W}\right)$ show very consistent results for $\mathrm{CO}$ contributions and $\delta^{18} \mathrm{O} . \delta^{18} \mathrm{O}$ source signatures are assumed to be constant over time since the mechanisms of $\mathrm{CO}$ production from different sources, such as fossil fuel combustion, biomass burning, $\mathrm{NMHC} / \mathrm{CH}_{4}$ oxidation, etc., are assumed to have been unchanged over the last 60 years. Concerning the impact of technological advancements on $\delta^{18} \mathrm{O}$ signature of the road transportation source (an important source in the following discussion), the $\delta^{18} \mathrm{O}$ signature from modern automobiles with catalytic converters is very similar to that from old automobiles without catalytic converters (Tsungaosi et al., 2003; Stevens et al., 1972). Diesel engine vehicles have depleted $\delta^{18} \mathrm{O}$ emissions compared to gasoline engine vehicles, but much smaller $\mathrm{CO}$ emissions. Thus, we believe that the impact of the diesel engine vehicle market share on $\mathrm{CO}$ isotopic composition is also very small. We thus believe technological advancements have a negligible impact on $\delta^{18} \mathrm{O}$ of $\mathrm{CO}$ from the road transportation source.

\subsection{Methane oxidation}

We can effectively determine the contribution of methane to $\mathrm{CO}$ by direct calculation. Assuming steady state, which is reasonable since the lifetime of $\mathrm{CO}$ is much shorter than the decadal scale we are interested in, the contribution of methane to $\mathrm{CO}$ is only dependent on the abundance of methane and the ratio of the rate constants for the $\mathrm{CH}_{4}-\mathrm{OH}$ and $\mathrm{CO}-\mathrm{OH}$ reactions (Eq. 3),

$[\mathrm{CO}]_{\mathrm{CH}_{4}}=k_{1} / k_{2} \times\left[\mathrm{CH}_{4}\right]$

where $[\mathrm{CO}]_{\mathrm{CH}_{4}}$ is the methane-derived [CO], $k_{1}$ is the rate constant of the $\mathrm{CH}_{4}+\mathrm{OH}$ reaction, $k_{2}$ is the rate constant of the $\mathrm{CO}+\mathrm{OH}$ reaction, and $\left[\mathrm{CH}_{4}\right]$ is the methane concentration. Assuming these rate constants have not changed with time since 1950, [CO] from methane oxidation at high northern latitudes is calculated based on an atmospheric methane concentration trend (Buizert et al., 2011) and the following equation:

$[\mathrm{CO}]_{\mathrm{CH}_{4}, n}=[\mathrm{CO}]_{\mathrm{CH}_{4,2000}} \times{ }^{\left[\mathrm{CH}_{4}\right]_{n}} /\left[\mathrm{CH}_{4}\right]_{2000}$

where $[\mathrm{CO}]_{\mathrm{CH}_{4, n}}$ is the methane-derived $[\mathrm{CO}]$ in the year " $n$ ", $[\mathrm{CO}]_{\mathrm{CH}_{4}, 2000}$ is the methane-derived $[\mathrm{CO}]$ in the year 2000 by MOZART-4 simulation and inverse model (Park, 2010), $\left[\mathrm{CH}_{4}\right]_{n}$ is the methane concentration in the year " $n$ ", and $\left[\mathrm{CH}_{4}\right]_{2000}$ is the methane concentration in the year 2000.

\subsection{Direct biogenic and marine emissions}

In order to reduce the number of parameters in the mass balance model, two minor sources, direct biogenic and marine emissions, are fixed at today's estimated values (Table 1). Marine emissions are dependent on the solar radiation (particularly UV irradiance) and dissolved organic matter (DOM) (Bauer et al., 1980; Conrad and Seiler, 1980). UV irradiance may have increased by $1.4 \%$ since 1610 (Lean et al., 1995). Large variations of global or hemispheric ocean DOM amounts did not likely occur either. Marine emissions are also tiny ( $1 \%$ of the whole). Direct biogenic emissions account for $4 \%$ of the CO budget and are likely a result of direct photochemical transformation occurring inside the leaf (Tarr et al., 1995). We thus assume that biogenic emissions are dependent on solar radiation and total aboveground biomass (or roughly vegetation area), both of which have been relatively constant over the time period of interest (Lean et al., 1995; Pongratz et al., 2008).

\subsection{Biomass/biofuel burning emissions}

Only two of the remaining three sources (biomass/biofuel burning, NMHC oxidation, and fossil fuel combustion) can be calculated. There are no observations indicating the degree of variation for historical NMHC-derived CO, so this emission is treated as an unknown. For biomass/biofuel burning and fossil fuel combustion, we choose to solve for fossil fuel instead of biomass burning because of the predominant impact of fossil fuel combustion source on $\mathrm{CO}$ isotopic ratio $\left(\delta^{18} \mathrm{O}\right)$ at high northern latitudes. Model simulations show that fossil fuel combustion and biomass burning account for $34 \%$ and $10 \%$ of the total CO emission, respectively (Table 1). Fossil fuel combustion is the most enriched source for ${ }^{18} \mathrm{O}$ (Table 1), which suggests it has the largest impact on 
Table 1. Atmospheric CO source contributions and $\delta^{18} \mathrm{O}$ at Iceland in Jan 1997-Dec 2004.

\begin{tabular}{lrrrr}
\hline Sources & $\begin{array}{r}{[\mathrm{CO}]_{\text {source }}^{\mathrm{a}}} \\
(\mathrm{ppbv})\end{array}$ & $\begin{array}{r}\text { Relative } \\
\text { contribution }\end{array}$ & $\begin{array}{r}\text { Source } \delta^{18} \mathrm{O} \\
(\%))^{\mathrm{b}}\end{array}$ & $\begin{array}{r}\delta^{18} \mathrm{O} \text { at Iceland } \\
(\% \circ)^{\mathrm{c}}\end{array}$ \\
\hline Fossil fuel & 46 & $34 \%$ & 24 & 20 \\
Methane oxidation & 29 & $21 \%$ & 0 & -9 \\
NMHC oxidation & 21 & $15 \%$ & 0 & -8 \\
Biofuel & 20 & $15 \%$ & 18 & 10 \\
Biomass burning & 14 & $10 \%$ & 18 & 9 \\
Biogenic & 5 & $4 \%$ & 0 & -5 \\
Ocean & 1 & $1 \%$ & 15 & 10 \\
\hline
\end{tabular}

Note: ${ }^{\text {a }}$ : these source contributions are a posteriori results based on MOZART- 4 and inverse model simulations (Park, 2010); ${ }^{\mathrm{b}}$ : these are original $\delta^{18} \mathrm{O}$ signatures used for each type of emission in the model; ${ }^{\mathrm{c}}: \delta^{18} \mathrm{O}$ values at Iceland are the isotopic ratios calculated in the model based on the source signatures. Note these $\delta^{18} \mathrm{O}$ values reflect the fractionation of $\mathrm{CO}$ after undergoing oxidation by $\mathrm{OH}$ during the transport (Wang et al., 2010). Data after Park (2010).

$\delta^{18} \mathrm{O}$ of CO. More importantly, the $\delta^{18} \mathrm{O}$ value of biomass burning at high northern latitudes $\left(9 \%\right.$ ) is close to the $\delta^{18} \mathrm{O}$ of our firn air observations (7-10\%), indicating that a significant biomass burning source change has only a small impact on firn $\delta^{18} \mathrm{O}$. Even though fossil fuel emission estimates are more accurate than biomass burning estimates, a relatively small variation of the former may have a larger impact than the uncertainty in biomass burning emissions on our calculation. Therefore we choose to solve for fossil fuel instead of biomass burning.

The biomass burning contribution is calculated from present-day model simulations at Iceland for the years 19972004 (Table 1) and historical biomass burning reconstructions. We use historical Northern Hemisphere CO emissions from biomass burning between 1950 and 2000 (Ito and Penner, 2005) and biomass burning CO contribution at Iceland in 1997-2004 from MOZART-4 and inverse model simulations (Table 1, Park, 2010) to scale the biomass burning contribution at the NEEM site since 1950 (See Fig. 5). An uncertainty of $\pm 50 \%$ is assigned to the scaling based on the uncertainty suggested in Ito and Penner, 2005. The CO contribution from biomass burning has a $\pm 35 \%$ uncertainty if we use historical global biomass burning $\mathrm{CO}$ emission data instead of Northern Hemisphere biomass burning CO emission data (Ito and Penner, 2005). CO contributions from biomass burning calculated from other databases and model simulations (van Aardenne et al., 2001; Lamarque et al., 2010) as well as global wildfire simulations (Pechony and Shindell, 2010) are within $50 \%$ of the estimates used in this study.

$\mathrm{CO}$ derived from biofuels originates mainly from the Northern Hemisphere (Park, 2010). Between 1950 and 2000, biofuel use in Asia and Africa grew rapidly as a result of population growth, and they are now the dominant regions for such emissions (Fernandes et al., 2007). We use the same approach for biofuels as for biomass burning, applying both historical CO emissions from biofuel burning in 1950-2000 (Ito and Penner, 2005) and calculated biofuel-derived CO at
Iceland in 1997-2004 from MOZART-4 and inverse model simulations (Table 1) to scale the biofuel burning contribution at the NEEM site since 1950 (Fig. 5). Again, an uncertainty of $\pm 50 \%$ is used in the scaling based on the uncertainties suggested in Ito and Penner, 2005. The range of these two estimates is within the assigned uncertainty. Results based on other historical global biofuel burning $\mathrm{CO}$ emission model simulations (van Aardenne et al., 2001) are also within the $\pm 50 \%$ envelope. The biomass and biofuel burning inventory during 1997-2000 used in MOZART-4 simulation is within the uncertainty of those in historical reconstructions (Ito and Penner, 2005). The 1997-2000 CO contributions calculated by MOZART- 4 and inverse model simulation also agree well with those from the scaling method decribed above, except for the year 1998, which is affected by large wildfires.

\subsection{Fossil fuel combustion and NMHC oxidation}

The two remaining variables are fossil fuel combustion and NMHC oxidation, which can be evaluated from the above equations based on the $\mathrm{CO}$ reconstruction data from LGGEGIPSA models (Fig. 3).

The temporal evolution of $\mathrm{CO}$ partitioning between fossil fuel combustion and NMHC oxidation since 1950 calculated by the isotope mass balance model (Wang et al., 2010) is shown in Fig. 6. It clearly suggests a dominant control from fossil fuel combustion variation at high northern latitudes since 1950 on the CO trend (Fig. 3). CO from methane oxidation has continuously increased since 1950, and since methane-derived $\mathrm{CO}$ is depleted in ${ }^{18} \mathrm{O}$, this would lead to a decrease in $\delta^{18} \mathrm{O}$. We see no evidence for a significant change in NMHC oxidation since 1950. However, large changes in $\mathrm{CO}$ emission from fossil fuel combustion are suggested to have occurred since 1950. CO from fossil fuel combustion increased slightly from 1950 to the mid-1970s, and decreased since then by $\sim 30 \%$ from the mid-1970s to 2000 . CO from fossil fuel combustion was as large as $56 \%$ of all CO sources at high northern latitudes in 1950, and this is much larger 
than the present day contribution (34\% in Table 1). The increase of [CO] from 1950 to the mid-1970s is thus the result of a combined increase of all sources except for the two fixed sources. The decrease of $\delta^{18} \mathrm{O}$ during this time is mainly caused by the increase in $\mathrm{CO}$ from methane oxidation. The simultaneous decrease of $\mathrm{CO}$ and $\delta^{18} \mathrm{O}$ after the mid-1970s requires the decrease of $\mathrm{CO}$ contribution from fossil fuel combustion during this time.

In the above mass balance calculations, $\mathrm{OH}$ is assumed to be constant, and model simulations use a seasonally varying, perpetual annual $\mathrm{OH}$ field. It is possible, however, that the removal rate of $\mathrm{CO}$ by $\mathrm{OH}$ could have changed. Previous studies have shown that interannual variations in $\mathrm{OH}$ abundance are less than $10 \%$ since the late 1970s (Prinn et al., 2005; Bousquet et al., 2005). A recent study even suggests that the interannual variability of global $[\mathrm{OH}]$ was less than 5\% during 1985-2008 (Montzka et al., 2011). As mentioned in Petrenko et al., 2012, the possible few percent increase of $[\mathrm{OH}]$ during the 1980 s could still partially have caused the decrease of [CO] after 1980 and slightly attenuate our strong decrease of $[\mathrm{CO}]$ from fossil fuel combustion during that time. However, there is no evidence of significant variations in $\mathrm{OH}$ during the time period of interest and we find it unlikely that a significant component of the temporal variations in $\mathrm{CO}$ observations is a result of variations in atmospheric $\mathrm{OH}$.

\subsection{Interpretation}

MOZART-4 simulations show that $\mathrm{CO}$ at high northern latitudes originates from three major regions: North America, Western Europe, and Northern Asia (Park, 2010). The historical fossil fuel $\mathrm{CO}_{2}$ emissions in 1950-2006 for these three regions are shown in Fig. 7. $\mathrm{CO}_{2}$ emissions from fossil fuel combustion increased from 1950 to the mid-1970s, implying an increase of $\mathrm{CO}$ emissions from fossil fuel combustion during this time (Fig. 6). On the other hand, the decrease of CO contribution after the mid-1970s from our calculation (Fig. 6c) goes opposite with a net $\mathrm{CO}_{2}$ emission increase of $\sim 20 \%$ between the mid-1970s and 2000 .

We propose that the reduction of $\mathrm{CO}$ from fossil fuel combustion after the mid-1970s reflects the implementation of catalytic converters in thermal-engine vehicles in North America during this time. The catalytic converter was installed in vehicles since the mid-1970s in the United States and Canada (Kummer, 1980; Young and Finlayson, 1976). Catalytic converters effectively reduce the $\mathrm{CO}$ emission from vehicle exhaust (Tsunogai et al., 2003) based on the catalyzed oxidation reaction $2 \mathrm{CO}+\mathrm{O}_{2} \rightarrow \mathrm{CO}_{2}$ (Kummer, 1986; Santra and Goodman, 2002) and their use resulted in a significant decrease of on-road vehicle $\mathrm{CO}$ emissions in the US since 1975 (Parrish, 2006). CO emissions from fossil fuel combustion would thus have dropped since the mid-1970s, counteracting the $\mathrm{CO}$ growth due to the concomitant $\mathrm{CH}_{4}$ increase.

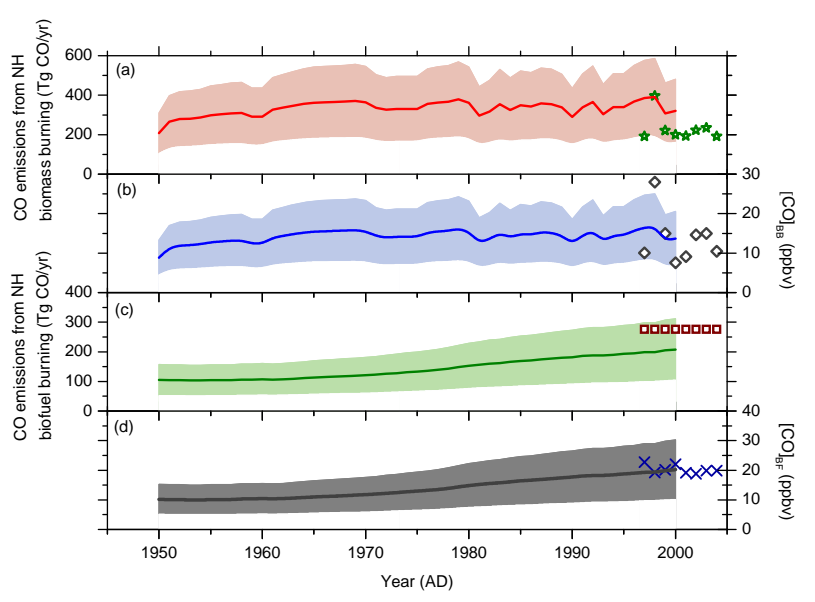

Fig. 5. (a) and (c): Estimated CO emissions from Northern Hemisphere biomass and biofuel burning $\left(\mathrm{Tg} \mathrm{CO} \mathrm{yr}^{-1}\right)$ based on model simulation (Ito and Penner, 2005). Also shown are 1997-2004 Northern Hemisphere CO emission inventory of biomass burning (van der Werf et al., 2006) (green stars) and biofuel burning (Petron et al., 2004) (red squares), used in MOZART-4 simulation (Park, 2010). (b) and (d): Calculated CO contribution (ppbv) from biomass $\left([\mathrm{CO}]_{\mathrm{BB}}\right)$ and biofuel $\left([\mathrm{CO}]_{\mathrm{BF}}\right)$ burning by scaling (see text), which is used in the isotope mass balance model. Also shown are CO contributions from biomass burning (grey diamonds) and biofuel burning (blue crosses) at high northern latitudes in MOZART-4 simulation (Park, 2010). Shaded areas show the $\pm 50 \%$ uncertainty for estimating both biomass burning and biofuel burning emissions.

Catalytic converters were introduced in Europe in 1975 and became mandatory in 1993. As a result, CO emissions from fossil fuel combustion in Europe have likely decreased since the 1990s, which can be seen in different emission inventories (Granier et al., 2011). Moreover, growth of market share for diesel engine vehicles, improvements in the automobile technologies including three-way oxidation/reduction catalytic converters, electronic ignition, fuel injection, and engine computer control in the period 1990present have possibly resulted in further reductions in vehicle $\mathrm{CO}$ emissions.

Lead in gasoline can "poison" catalytic converters by coating the surface of the catalyst. Vehicle manufacturers thus required the oil companies to remove lead from gasoline and substitute it with other chemical compounds to maintain the octane number (methyl tert-butyl ether (MTBE) in the USA, or higher concentration of benzene, toluene, ethylbenzene and xylenes (BTEX) in Europe). The temporal variations of leaded gasoline consumption in North America and Europe should roughly reflect the timeline of the application of catalytic converters. In the US, the first step of gradual reduction of lead in gasoline started in the early 1970s, which preceded the application of catalytic converters. This suggests the decrease of leaded gasoline consumption preceded the decrease of $\mathrm{CO}$ emissions from fossil fuel combustion. The historical leaded gasoline consumption in the US and Western Europe 


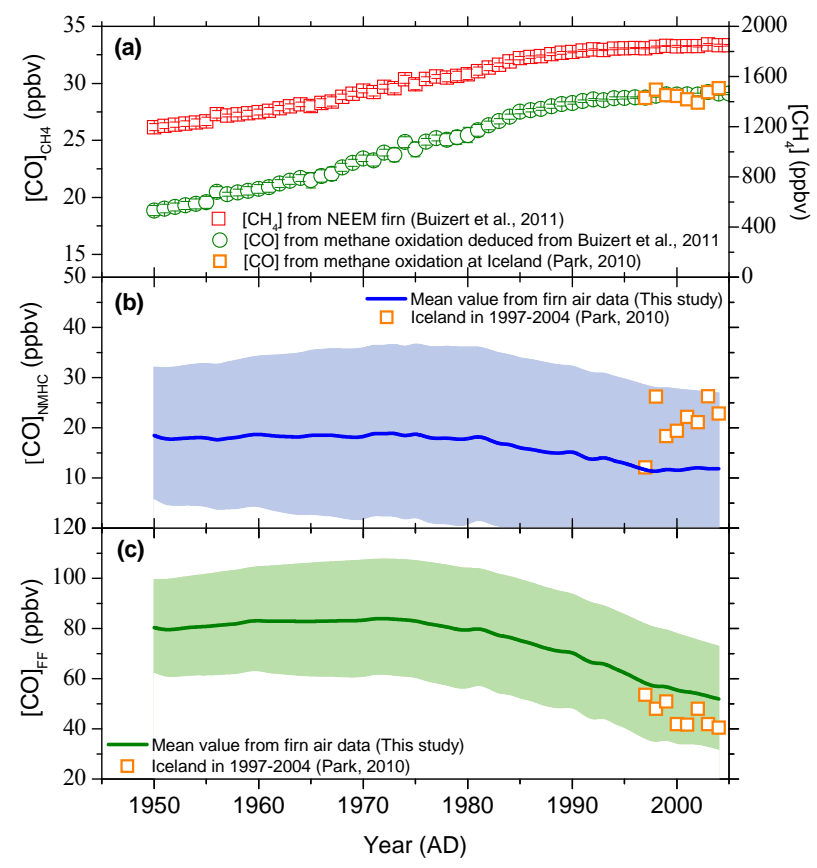

Fig. 6. Modeled CO source partitioning based on observations and isotope mass balance model: (a): Methane atmospheric trend at high northern latitude (Buizert et al., 2011) (red squares) and [CO] from methane oxidation $\left([\mathrm{CO}]_{\mathrm{CH}_{4}}\right.$ ) deduced from the methane concentration (green circles), (b): [CO] from NMHC oxidation ([CO $]_{\mathrm{NMHC}}$ ), and (c): $[\mathrm{CO}]$ from fossil fuel combustion $\left([\mathrm{CO}]_{\mathrm{FF}}\right)$. Thick lines in (b) and (c) represent the mean values of different scenarios and shaded areas represent the uncertainties which arise from the LGGE-GIPSA models simulation uncertainties on both $\mathrm{CO}$ concentration and $\delta^{18} \mathrm{O}$, as well as the uncertainties for estimating historical $\mathrm{CO}$ emissions from biofuel and biomass burning (Ito and Penner, 2005). [CO] derived from the three major sources since 1950 is calculated based on an isotope mass balance model (Wang et al., 2010). CO source partitioning at present day is calculated based on MOZART-4 and inverse modeling and CO measurements in 1997-2004 at Iceland (orange squares) (Park, 2010).

between 1930 and 1990 indicates that the consumption of leaded gasoline increased sharply in the 1950s and 1960s, remained high until about 1970 and started to decrease in the early 1970s (Wu and Boyle, 1997, and reference therein). Furthermore, vehicle lead emissions in the US dropped more than $99 \%$, from 156003 metric tons in 1970 to 17 metric tons in 1998 (EPA, 2000). The drop of lead emissions from vehicles was followed by that of $\mathrm{CO}$ emissions from fossil fuel combustion.

\section{Conclusions}

In this study, we present the first record of isotopic ratios of carbon monoxide at high northern latitudes since 1950 based on measurements on NEEM firn air and the use of the LGGE-GIPSA models of gas transport in firn. Combined

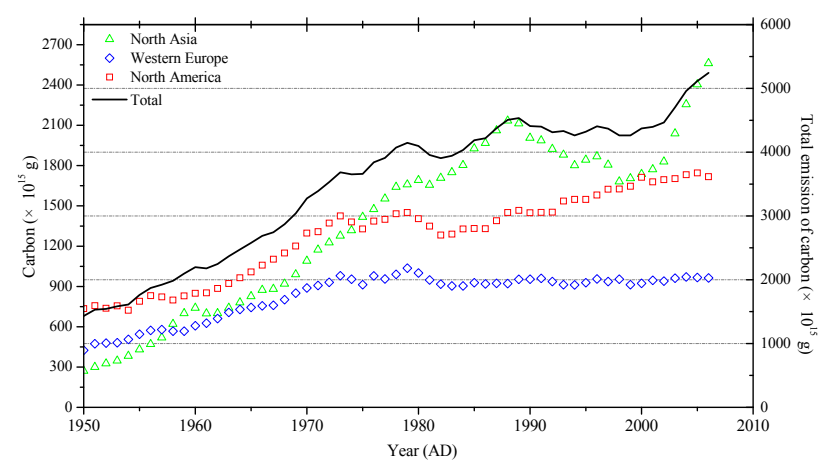

Fig. 7. Fossil fuel $\mathrm{CO}_{2}$ emissions in these mid-high latitude Northern Hemisphere regions (Marland et al., 2008). Symbols link to left $\mathrm{y}$-axis and indicate the $\mathrm{CO}_{2}$ emissions in three different regions: green triangles: North Asia; blue diamonds: Western Europe; red squares: North America. Black line links to right y-axis and stands for the sum of $\mathrm{CO}_{2}$ emissions from the above three regions.

with the $\mathrm{CO}$ reconstruction from different measurement sets on the same firn air (Petrenko et al., 2012) and an isotope mass balance model, we calculated the temporal evolution of CO source partitioning since 1950. Mass balance model results suggest that variations in fossil fuel-derived $\mathrm{CO}$ are the primary factor behind the observed $\mathrm{CO}$ concentration and its $\delta^{18} \mathrm{O}$ trends at high northern latitude since 1950. The decrease of $\mathrm{CO}$ emission from fossil fuel combustion since the mid-1970s is ascribed to the invention and application of catalytic converters in the Northern Hemisphere and the growth of diesel engine vehicle market share in Europe, both of which reduce $\mathrm{CO}$ emissions from vehicles.

\section{Supplementary material related to this article is available online at: http://www.atmos-chem-phys.net/12/ 4365/2012/acp-12-4365-2012-supplement.pdf.}

Acknowledgements. We sincerely thank J. F. Lamarque, O. Pechony, and A. Ito for sharing with us the biomass/biofuel burning reconstruction data. NEEM is directed and organized by the Center of Ice and Climate at the Niels Bohr Institute and US NSF, Office of Polar Programs. It is supported by funding agencies and institutions in Belgium (FNRS-CFB and FWO), Canada (NRCan/GSC), China (CAS), Denmark (FIST), France (IPEV, CNRS/INSU, CEA and ANR), Germany (AWI), Iceland (RannIs), Japan (NIPR), Korea (KOPRI), The Netherlands (NWO/ALW), Sweden (VR), Switzerland (SNF), United Kingdom (NERC) and the USA (US NSF, Office of Polar Programs). This work was supported by the National Science Foundation grant OCE0731406, the European Science Foundation (ESF) EURO-CORES Programme EuroCLIMATE (contract ERAS-CT-2003-980409 of the European Commission, DG Research, FP6), Institut National des Sciences de l'Univers (INSU) project ISOTRACE-FP21, and the French ANR NEEM (ANR-O7-VULN-09-001). This work has also received funding 
from the European Community's Seventh Framework Programme (FP7) in the project PEGASOS (grant agreement 265148). We would like to acknowledge high-performance computing support provided by NCAR's Computational and Information Systems Laboratory, sponsored by the National Science Foundation. The National Center for Atmospheric Research is funded by the National Science Foundation.

Edited by: R. van de Wal

\section{References}

Assonov, S. S., Brenninkmeijer, C. A. M., Jöckel, P., Mulvaney, R., Bernard, S., and Chappellaz, J.: Evidence for a CO increase in the SH during the 20th century based on firn air samples from Berkner Island, Antarctica, Atmos. Chem. Phys., 7, 295-308, doi:10.5194/acp-7-295-2007, 2007.

Bauer, K., Conrad, R., and Seiler, W.: Photo-oxidative production of carbon monoxide by phototropic mocroorganisms, Biochim. Biophys. Acta, 589, 46-55, 1980.

Bergamaschi, P., Hein, R., Brenninkmeijer, C. A. M., and Crutzen, P. J.: Inverse modeling of the global CO cycle 2. Inversion of ${ }^{13} \mathrm{C} /{ }^{12} \mathrm{C}$ and ${ }^{18} \mathrm{O} /{ }^{16} \mathrm{O}$ isotope ratios, J. Geophys. Res.-Atmos., 105, 1929-1945, 2000a.

Bergamaschi, P., Hein, R., Heimann, M., and Crutzen, P. J.: Inverse modeling of the global $\mathrm{CO}$ cycle 1 . Inversion of $\mathrm{CO}$ mixing ratios, J. Geophys. Res.-Atmos., 105, 1909-1927, 2000 b.

Bousquet, P., Hauglustaine, D. A., Peylin, P., Carouge, C., and Ciais, P.: Two decades of $\mathrm{OH}$ variability as inferred by an inversion of atmospheric transport and chemistry of methyl chloroform, Atmos. Chem. Phys., 5, 2635-2656, doi:10.5194/acp-52635-2005, 2005.

Brenninkmeijer, C. A. M.: Measurement of the abundance of ${ }^{14} \mathrm{CO}$ in the atmosphere and the ${ }^{13} \mathrm{C} /{ }^{12} \mathrm{C}$ and ${ }^{18} \mathrm{O} /{ }^{16} \mathrm{O}$ ratio of atmospheric CO with applications in New Zealand and Antarctica, J. Geophys. Res.-Atmos., 98, 10595-10614, 1993.

Brenninkmeijer, C. A. M. and Röckmann, T.: Principal factors determining the ${ }^{18} \mathrm{O} /{ }^{16} \mathrm{O}$ ratio of atmospheric $\mathrm{CO}$ as derived from observations in the southern hemispheric troposphere and lowermost stratosphere, J. Geophys. Res.-Atmos., 102, 25477-25485, 1997.

Buizert, C., Martinerie, P., Petrenko, V. V., Severinghaus, J. P., Trudinger, C. M., Witrant, E., Rosen, J. L., Orsi, A. J., Rubino, M., Etheridge, D. M., Steele, L. P., Hogan, C., Laube, J. C., Sturges, W. T., Levchenko, V. A., Smith, A. M., Levin, I., Conway, T. J., Dlugokencky, E. J., Lang, P. M., Kawamura, K., Jenk, T. M., White, J. W. C., Sowers, T., Schwander, J., and Blunier, T.: Gas transport in firn: multiple-tracer characterisation and model intercomparison for NEEM, Northern Greenland, Atmos. Chem. Phys., 12, 4259-4277, doi:10.5194/acp-12-4259-2012, 2012.

Clark, I. D., Henderson, L., Chappellaz, J., Fisher, D., Koerner, R., Worthy, D. E. J., Kotzer, T., Norman, A. L., and Barnola, J. M.: $\mathrm{CO}_{2}$ isotopes as tracers of firn air diffusion and age in an Arctic ice cap with summer melting, Devon Island, Canada, J. Geophys. Res.-Atmos., 112, D01301, doi:10.1029/2006jd007471, 2007.

Conrad, R. and Seiler, W.: Photooxidative production and microbial consumption of carbon monoxide in seawater, Fems Microbiol. Lett., 9, 61-64, 1980.
Duncan, B. N., Logan, J. A., Bey, I., Megretskaia, I. A., Yantosca, R. M., Novelli, P. C., Jones, N. B., and Rinsland, C. P.: Global budget of CO, 1988-1997: Source estimates and validation with a global model, J. Geophys. Res.-Atmos., 112, D22301, doi:10.1029/2007jd008459, 2007.

Emmons, L. K., Walters, S., Hess, P. G., Lamarque, J.-F., Pfister, G. G., Fillmore, D., Granier, C., Guenther, A., Kinnison, D., Laepple, T., Orlando, J., Tie, X., Tyndall, G., Wiedinmyer, C., Baughcum, S. L., and Kloster, S.: Description and evaluation of the Model for Ozone and Related chemical Tracers, version 4 (MOZART-4), Geosci. Model Dev., 3, 43-67, doi:10.5194/gmd3-43-2010, 2010.

EPA: National air pollutant emission trends: 1900-1998, EPA Report 454/R-00-002, United States Environmental Protection Agency, Research Triangle Park, NC 27711, 2000.

Fernandes, S. D., Trautmann, N. M., Streets, D. G., Roden, C. A., and Bond, T. C.: Global biofuel use, 1850-2000, Global Biogeochem. Cy., 21, Gb2019, doi:10.1029/2006gb002836, 2007.

Ferretti, D. F., Miller, J. B., White, J. W. C., Etheridge, D. M., Lassey, K. R., Lowe, D. C., Macfarling Meure, C. M. M., Dreier, M. F., Trudinger, C. M., van Ommen, T. D., and Langenfelds, R. L.: Unexpected changes to the global methane budget over the past 2000 years, Science, 309, 1714-1717, doi:10.1126/science.1115193, 2005.

Francey, R. J., Allison, C. E., Etheridge, D. M., Trudinger, C. M., Enting, I. G., Leuenberger, M., Langenfelds, R. L., Michel, E., and Steele, L. P.: A 1000-year high precision record of $\delta^{13} \mathrm{C}$ in atmospheric $\mathrm{CO}_{2}$, Tellus B, 51, 170-193, 1999.

Granier, C., Bessagnet, B., Bond, T., D’Angiola, A., van der Gon, H. D., Frost, G. J., Heil, A., Kaiser, J. W., Kinne, S., Klimont, Z., Kloster, S., Lamarque, J.-F., Liousse, C., Masui, T., Meleux, F., Mieville, A., Ohara, T., Raut, J.-C., Riahi, K., Schultz, M. G., Smith, S. J., Thompson, A., van Aardenne, J., van der Werf, G. R., and van Vuuren, D. P.: Evolution of anthropogenic and biomass burning emissions of air pollutants at global and regional scales during the 1980-2010 period, Climatic Change, 109, 163-190, doi:10.1007/s10584-011-0154-1, 2011.

Haan, D. and Raynaud, D.: Ice core record of $\mathrm{CO}$ variations during the last two millennia: atmospheric implications and chemical interactions within the Greenland ice, Tellus B, 50, 253-262, 1998.

Haan, D., Martinerie, P., and Raynaud, D.: Ice core data of atmospheric carbon monoxide over Antarctica and Greenland during the last 200 years, Geophys. Res. Lett., 23, 2235-2238, 1996.

Heidt, L. E., Krasnec, J. P., Lueb, R. A., Pollock, W. H., Henry, B. E., and Crutzen, P. J.: Latitudinal distributions of $\mathrm{CO}$ and $\mathrm{CH}_{4}$ over the Pacific, J. Geophys. Res.-Oc. Atm., 85, 7329-7336, 1980.

Ito, A. and Penner, J. E.: Historical emissions of carbonaceous aerosols from biomass and fossil fuel burning for the period 1870-2000, Global. Biogeochem. Cy., 19, Gb2028, doi:10.1029/2004gb002374, 2005.

Kato, S., Akimoto, H., Röckmann, T., Braunlich, M., and Brenninkmeijer, C. A. M.: Stable isotopic compositions of carbon monoxide from biomass burning experiments, Atmos. Environ., 33, 4357-4362, 1999.

Khalil, M. A. K. and Rasmussen, R. A.: Carbon monoxide in the earth's atmosphere: increased trend, Science, 224, 54-56, 1984.

Khalil, M. A. K. and Rasmussen, R. A.: Global decrease in atmospheric carbon monoxide concentration, Nature, 370, 639-641, 
1994.

Kummer, J. T.: Catalysis for automobile emission control, Prog. Energ. Combust., 6, 177-199, 1980.

Kummer, J. T.: Use of noble-metals in automobile exhaust catalysts, J. Phys. Chem.-US, 90, 4747-4752, doi:10.1021/j100411a008, 1986.

Lamarque, J.-F., Bond, T. C., Eyring, V., Granier, C., Heil, A., Klimont, Z., Lee, D., Liousse, C., Mieville, A., Owen, B., Schultz, M. G., Shindell, D., Smith, S. J., Stehfest, E., Van Aardenne, J., Cooper, O. R., Kainuma, M., Mahowald, N., McConnell, J. R., Naik, V., Riahi, K., and van Vuuren, D. P.: Historical (1850-2000) gridded anthropogenic and biomass burning emissions of reactive gases and aerosols: methodology and application, Atmos. Chem. Phys., 10, 7017-7039, doi:10.5194/acp10-7017-2010, 2010.

Lean, J., Beer, J., and Bradley, R.: Reconstruction of solar irradiance since 1610 - implications for climate change, Geophys. Res. Lett., 22, 3195-3198, 1995.

Levy, H.: Normal atmosphere - Large radical and formaldehyde concentrations predicted, Science, 173, 141-143, 1971.

Logan, J. A., Prather, M. J., Wofsy, S. C., and McElroy, M. B.: Tropospheric chemistry: a global perspective, J. Geophys. Res.-Oc. Atm., 86, 7210-7254, 1981.

Mak, J. E. and Brenninkmeijer, C. A. M.: Measurement of ${ }^{13} \mathrm{CO}$ and $\mathrm{C}^{18} \mathrm{O}$ in the free troposphere, J. Geophys. Res.-Atmos., 103, 19347-19358, 1998.

Mak, J. E. and Kra, G.: The isotopic composition of carbon monoxide at Montauk Point, Long Island, Chemosphere: Global Change Science, 1, 205-218, 1999.

Mak, J. E., Kra, G., Sandomenico, T., and Bergamaschi, P.: The seasonally varying isotopic composition of the sources of carbon monoxide at Barbados, West Indies, J. Geophys. Res.-Atmos., 108, 4635, doi:10.1029/2003jd003419, 2003.

Manning, M. R., Brenninkmeijer, C. A. M., and Allan, W.: Atmospheric carbon monoxide budget of the southern hemisphere: Implications of ${ }^{13} \mathrm{C} /{ }^{12} \mathrm{C}$ measurements, J. Geophys. Res.-Atmos., 102, 10673-10682, 1997.

Marland, G., Boden, T. A., and Andres, R. J.: Global, Regional, and National Fossil-Fuel $\mathrm{CO}_{2}$ Emissions, in: Trends: A Compendium of Data on Global Change, Carbon Dioxide Information Analysis Center, Oak Ridge National Laboratory, US Department of Energy, Oak Ridge, Tenn., USA, 2008.

Montzka, S. A., Krol, M., Dlugokencky, E., Hall, B., Jockel, P., and Lelieveld, J.: Small Interannual Variability of Global Atmospheric Hydroxyl, Science, 331, 67-69, doi:10.1126/science.1197640, 2011.

Novelli, P. and Masarie, K. A.: Atmospheric Carbon Monoxide Dry Air Mole Fractions from the NOAA ESRL Carbon Cycle Cooperative Global Air Sampling Network, 1988-2009, Version: 2010-07-14, Path: ftp://ftp.cmdl.noaa.gov/ccg/co/flask/ event/, last access: November 2011, 2010.

Novelli, P. C., Steele, L. P., and Tans, P. P.: Mixing ratios of carbon monoxide in the troposphere, J. Geophys. Res.-Atmos., 97, 20731-20750, 1992.

Novelli, P. C., Masarie, K. A., Tans, P. P., and Lang, P. M.: Recent changes in atmospheric carbon monoxide, Science, 263, 15871590, 1994.

Park, K.: Joint Application of Concentration and Isotope Ratios to Investigate the Global Atmospheric Carbon Monoxide Budget:
An Inverse Modeling Approach, PhD Thesis, Stony Brook University, Stony Brook, NY, USA, 2010.

Parrish, D. D.: Critical evaluation of US on-road vehicle emission inventories, Atmos. Environ., 40, 2288-2300, doi:10.1016/j.atmosenv.2005.11.033, 2006.

Pechony, O. and Shindell, D. T.: Driving forces of global wildfires over the past millennium and the forthcoming century, Proc. Natl. Acad. Sci. U.S.A., 107, 19167-19170, doi:10.1073/pnas.1003669107, 2010.

Petrenko, V., Martinerie, P., Novelli, P., Etheridge, D. M., Levin, I., Wang, Z., Petron, G., Blunier, T., Chappellaz, J., Kaiser, J., Lang, P., Steele, L. P., Vogel, F., Leist, M. A., Mak, J., Langenfelds, R. L., Schwander, J., Severinghaus, J. P., Forster, G., Sturges, W., Rubino, M., and White, J. W. C.: Records of Northern Hemisphere carbon monoxide and hydrogen back to $\sim 1950$ from Greenland firn air, Atmos. Chem. Phys., in preparation, 2012.

Petron, G., Granier, C., Khattatov, B., Yudin, V., Lamarque, J. F., Emmons, L., Gille, J., and Edwards, D. P.: Monthly CO surface sources inventory based on the 20002001 MOPITT satellite data, Geophys. Res. Lett., 31, L21107 doi:10.1029/2004g1020560, 2004.

Pongratz, J., Reick, C., Raddatz, T., and Claussen, M.: A reconstruction of global agricultural areas and land cover for the last millennium, Global Biogeochem. Cy., 22, GB3018, doi:10.1029/2007gb003153, 2008.

Prinn, R. G., Huang, J., Weiss, R. F., Cunnold, D. M., Fraser, P. J., Simmonds, P. G., McCulloch, A., Harth, C., Reimann, S., Salameh, P., O'Doherty, S., Wang, R. H. J., Porter, L. W., Miller, B. R., and Krummel, P. B.: Evidence for variability of atmospheric hydroxyl radicals over the past quarter century, Geophys. Res. Lett., 32, L07809, doi:10.1029/2004g1022228, 2005.

Rinsland, C. P. and Levine, J. S.: Free tropspheric carbon monoxide concentrations in 1950 and 1951 deduced from infrared total column amount measurements, Nature, 318, 250-254, 1985.

Röckmann, T., Jöckel, P., Gros, V., Bräunlich, M., Possnert, G., and Brenninkmeijer, C. A. M.: Using ${ }^{14} \mathrm{C},{ }^{13} \mathrm{C},{ }^{18} \mathrm{O}$ and ${ }^{17} \mathrm{O}$ isotopic variations to provide insights into the high northern latitude surface CO inventory, Atmos. Chem. Phys., 2, 147-159, doi:10.5194/acp-2-147-2002, 2002

Rommelaere, V., Arnaud, L., and Barnola, J. M.: Reconstructing recent atmospheric trace gas concentrations from polar firn and bubbly ice data by inverse methods, J. Geophys. Res.-Atmos., 102, 30069-30083, 1997.

Santra, A. K. and Goodman, D. W.: Catalytic oxidation of CO by platinum group metals: from ultrahigh vacuum to elevated pressures, Electrochim. Acta, 47, 3595-3609, PII S00134686(02)00330-4, doi:10.1016/S0013-4686(02)00330-4, 2002.

Schwander, J. and Stauffer, B.: Age Difference between Polar Ice and the Air Trapped in Its Bubbles, Nature, 311, 45-47, 1984.

Seiler, W.: Cycle of atmospheric CO, Tellus, 26, 116-135, 1974.

Seiler, W. and Junge, C.: Carbon monoxide in atmosphere, J. Geophys. Res., 75, 2217-2226, 1970.

Stevens, C. M., Walling, D., Venters, A., Ross, L. E., Engelkem, A., and Krout, L.: Isotopic Composition of Atmospheric CarbonMonoxide, Earth Planet. Sc. Lett., 16, 147-165, 1972.

Stevens, C. M., and Wagner, A. F.: The Role of Isotope Fractionation Effects in Atmospheric Chemistry, Z. Naturforsch. A, 44, 376-384, 1989. 
Tarr, M. A., Miller, W. L., and Zepp, R. G.: Direct carbon monoxide photoproduction from plant matter, J. Geophys. Res.-Atmos., 100, 11403-11413, 1995.

Trudinger, C. M., Enting, I. G., Etheridge, D. M., Francey, R. J., Levchenko, V. A., Steele, L. P., Raynaud, D., and Arnaud, L.: Modeling air movement and bubble trapping in firn, J. Geophys. Res.-Atmos., 102, 6747-6763, 1997.

Tsunogai, U., Hachisu, Y., Komatsu, D. D., Nakagawa, F., Gamo, T., and Akiyama, K.: An updated estimation of the stable carbon and oxygen isotopic compositions of automobile CO emissions, Atmos. Environ., 37, 4901-4910, doi:10.1016/j.atmosenv.2003.08.008, 2003.

van Aardenne, J. A., Dentener, F. J., Olivier, J. G. J., Goldewijk, C., and Lelieveld, J.: A 1 degrees $\times 1$ degrees resolution data set of historical anthropogenic trace gas emissions for the period 1890 1990, Global Biogeochem. Cy., 15, 909-928, 2001.

van der Werf, G. R., Randerson, J. T., Giglio, L., Collatz, G. J., Kasibhatla, P. S., and Arellano Jr., A. F.: Interannual variability in global biomass burning emissions from 1997 to 2004, Atmos. Chem. Phys., 6, 3423-3441, doi:10.5194/acp-6-3423-2006, 2006.
Wang, Z. and Mak, J. E.: A new CF-IRMS system for quantifying stable isotopes of carbon monoxide from ice cores and small air samples, Atmos. Meas. Tech., 3, 1307-1317, doi:10.5194/amt-31307-2010, 2010.

Wang, Z., Chappellaz, J., Park, K., and Mak, J. E.: Large Variations in Southern Hemisphere Biomass Burning During the Last 650 Years, Science, 330, 1663-1666, doi:10.1126/science.1197257, 2010.

Witrant, E., Martinerie, P., Hogan, C., Laube, J. C., Kawamura, K., Capron, E., Montzka, S. A., Dlugokencky, E. J., Etheridge, D., Blunier, T., and Sturges, W. T.: A new multi-gas constrained model of trace gas non-homogeneous transport in firn: evaluation and behavior at eleven polar sites, Atmos. Chem. Phys. Discuss. 11, 23029-23080, doi:10.5194/acpd-11-23029-2011, 2011.

Wu, J. and Boyle, E. A.: Lead in the western North Atlantic Ocean: completed response to leaded gasoline phase-out, Geochim. Cosmochim. Acta, 61, 3279-3283, 1997.

Young, L. C. and Finlayson, B. A.: Mathematical models of monolith catallytic converter 2: application to automobile exhaust, Aiche J., 22, 343-353, 1976. 